\title{
Stock Prices and Consumption: Sub-Sahara African Experience
}

\author{
Lukman O. Oyelami ${ }^{1}$, Ebenezer Y. Akinkoye ${ }^{2}$ \& Emmanuel O. Dunmade ${ }^{1}$ \\ ${ }^{1}$ Wesley University of Science and Technology, Ondo State, Nigeria \\ ${ }^{2}$ Obafemi Awolowo University, Ile-ife Osun State, Nigeria \\ Correspondence: Lukman O. Oyelami, Wesley University of Science and Technology, Ondo State, Nigeria. \\ E-mail: oyelamilukman@yahoo.com
}

Received: September 17, 2013

Accepted: October 18, 2013

Online Published: November 26, 2013

doi:10.5539/ijef.v5n12p63

URL: http://dx.doi.org/10.5539/ijef.v5n12p63

\begin{abstract}
Abstact
This paper investigates the effect of stock market variables on consumption growth in 12 selected sub-Saharan African countries within the period 1988-2012 using dynamic panel estimation techniques. Specifically, we examine if consumption growth is in any way being influenced by stock returns and dividend yield. While the use of returns determines the existence of a wealth, dividend yield shows how consumption is affected by short-term disequilibrium of prices from fundamental value. Having critically examined the econometric properties of our data, the results from dynamic panel estimation support a significant direct relationship between stock price (returns) and consumption growth which implies the existence of wealth effect. Similarly, the results indicate insignificant positive relationship between the dividend yield and consumption growth which implies that bubbles in the market can increase consumption but with fear of future bust. Overall, we argue that consumption growth can be influenced by stock price (returns), thus policy-maker in the sub-region can leverage on this link to stimulate economic growth.
\end{abstract}

Keywords: consumption, dividend yield, stock price, growth

\section{Introduction}

Generally, given the importance of consumer spending on economic growth, it is imperative to investigate what drives this vital component of economic growth. To this end, several theories have been put forward in the literature regarding the determinants of consumer spending. Starting with the work of Keynes (1936) and Friedman (1957) which links consumption to absolute income and permanent income respectively, other theories of consumption have been well discussed in the literature.

Specifically, this paper set out to examine the relationship between stock price and consumption growth for developing economies of Sub-Sahara African countries (SSA). This is in an attempt to establishing or otherwise the existence of wealth effect for developing countries. It is of empirical importance because many monetary policies in the developing economies are predicated on similar assumptions in the developed countries. Based on this, it is imperative to investigate the existence of necessary mechanisms required for the efficacy of monetary policies in the developing countries of the world.

It has been argued in literature that stock prices affect consumption through different channels. Majorly through a direct wealth effect which is based on standard life-cycle model for consumption in the work of Modigliani and Brumberg $(1954 ; 1980)$. According to this assertion, households will deplete accumulated assets in order to maintain consumption at a relatively steady level. It is also predicted by the model that despite the possible movement in wealth level during the entire existence of a household, consumption will relatively remain unchanged. However, shock to wealth level can still bring about revision in consumption level. If changes in stock prices can be seen as shock to investment via the asset value then it should be of consequential value for household consumption through altering households' wealth. This is not new as the relevance of wealth effects have long been acknowledged in the literature (Hall, 1978).

Also, it is discussed in the life-cycle model that a raise in the value of asset (investment or saving) will bring about an increase in its share of the households' portfolio of total saving. This may necessitate readjustment in the households' portfolio, in a manner that will reduce their holdings of other forms of saving, which in turn may increase consumption (McMillan, 2013).These two alternative approaches work have direct effects on the budget constraint of households. It can also be argued that asset prices and consumption are both driven by a common 
macroeconomic factor rather than the former having a direct effect on the later. And this might be responsible for the linkage between stock market development and economic growth as discussed in many studies in the region (Gelbard \& Leite, 1999; Levine, 2003; Beck, 2006).

In many Sub Sahara African countries, a stock market activity is at infancy stage. According to Yartey and Adjasi (2007) prior to 1989 there were just five stock markets in Sub-Saharan Africa and three in North Africa and as at 2007 there were 19 stock exchanges market in the continent. This includes starts ups like Uganda and Mozambique stock exchanges to the Nigeria and Johannesburg stock exchanges. With the exception of South Africa, most African stock markets doubled their market capitalization between 1992 and 2002. Total market capitalization for African markets increased from US\$113,423 million to US\$244,672 million between 1992 and 2002. Apart from this introductory part which is section one; the study is divided into four sections. Section two presents addition stylized fact of stock market in Sub-Sahara African countries and section three examines the extant literature on stock market and consumption and by extension economic performance. Also, section four discusses the data and methodology employed in the study while section five presents the results and discussion of our findings.

\section{Stylized Fact of Stock Market in Sub-Saharan Africa}

Fifteen SSA countries have stock markets, of which most of them established over the past decade and remained immature. Except in South Africa and Zimbabwe, average market capitalization is about 27 percent of GDP; it is as low as 1.4 percent in Uganda (Regional Economic Outlook, 2006). This contrasts with emerging markets like Malaysia, which has a capitalization ratio of about 161 percent (Regional Economic Outlook, 2006). Market liquidity is also very low: turnover ratios are as little as 0.02 percent in Swaziland compared with about 29 percent in Mexico. In most SSA stock markets, informational and disclosure deficiencies prevent trading in most listed stocks. Further, supervision by regulatory authorities is often inadequate (Regional Economic Outlook, 2006).

Also, corporate financing pattern in certain SSA countries suggests that stock markets are important sources of finance. In Ghana, the stock market financed about 28 percent of total asset growth of listed companies between 1995-2002, 16 percent in South Africa between 1996-2000, and 8 percent in Zimbabwe between 1995-1999 (Regional Economic Outlook, 2006). In all the three countries, the stock markets were the most important sources of long-term finance for listed companies. Empirically, Enisan and Olufisayo (2009) examined the long run and causal relationship between stock market development and economic growth for seven countries in sub-Saharan Africa and found that the stock market development is co-integrated with economic growth in Egypt and South Africa. The result was suggestive of the fact that stock market development has a significant positive long run impact on economic growth in some of the countries in the region.

\section{Literature Review}

Basically, there are two strands of literature regarding stock price and consumption both at theoretical level and empirical level. At theoretical level, the first strand of literature pioneered by the work of Ando and Modigliani (1963) which is based around a standard life-cycle model argues that wealth effect as a result of increase in the price of stock can spur more consumption. To the contrary, based on Friedman (1957) it can be argued that since households might not see a rise in stock price as an increase in permanent income therefore it might not be of any consequence to their consumption as the consumption is not based on transitory income. More recently, the work of Lettau and Ludvigson (2004) upholds this argument in a more assertive manner.

From empirical point of view, the results are mixed with the bulk of the findings emanated from US. Prior to financial deregulation, empirical work on the United States reported a marginal propensity to consume out of wealth within the range of 4 to 8 per cent (Ando \& Modigliani, 1963; Modigliani, 1971; Bhatia, 1972). But this "consensus" was put into serious test with the 1987 crash when Cagan (1990) claimed wealth effect had no impact at all on consumption. Similarly, Deaton (1991), Carroll (1992), Wilhelm (1996) and Laitner and Juster (1996) also provided support for the argument in their works.

However, it was argued in the literature that the extensive financial deregulation might have weakened these specific criticisms and may indeed have swayed the argument in favour of wealth effects (Bayoumi, 1993; Caporale \& Williams, 1997). The articles by M. Starr-McCluer (1998) of the US Federal Reserve Board of Governors reports concluded that marginal propensity to consume out of stock market wealth is 0.03 to 0.07 , with the effect materialising over one to three years". Similarly, Brayton and Tinsley (1996), reported that, "In 1996, estimates from the FRB/US quarterly model placed the marginal propensity to consume at 0.03 for stock market wealth and 0.075 for other net wealth". 
Also, cross-sectional, time series and panel studies within and outside the US have reported mixed results. Parker (1999) directly addressed the question of whether the rise in stock prices in the 1990s could have contributed to the fall in the saving rate over the same period. Starr-McCluer (2002) used cross-section survey data in an effort to disentangle Poterba and Samwick's two channels and found some support for the traditional wealth effect, particularly for households with substantial stockholdings. An early study based on panel data is the one by Mankiw and Zeldes (1991) which focusses on the equity-premium puzzle and in which they examine separately for stockholding and non-stockholding consumers. In similar manner Ludwig and Sløk (2002) and Case et al. (2001) use a combination of cross-section and time-series data and arrived at the same results. In conclusion, it is worthy of note that the bulk of studies were carried out in the developed economies with little focus on developing economies of the world. This neglect necessitates this study and it is important to also test whether the claims in developed economies will also hold in the developing economies characterised with fast growing stock markets. Thus this study empirically investigates stock price and consumption nexus for developing economies of Sub-Saharan Africa.

\subsection{Theoretical Framework: Consumption and Dividend Yield}

In line with the work of Mc Millian (2013), the theoretical framework of this study is based on the work of Campbell (2003). In the model, the relationship between consumption and the price dividend ratio is presented in log-linear value prices change according to changes in expected future dividends and the (constant) discount rate. Thus the fundamental prices are given by:

$$
p_{t}=\sum_{t=1} \delta^{i} E_{t} D_{t+i}
$$

Where $\delta^{i}=1 /(1+R)$ is the discount factor and $\mathrm{R}$ the discount rate. Where log returns are given by $r_{t} \equiv \log \left(P_{t}+D_{t}\right)-\log \left(P_{t-1}\right)$ and where the time-varying $\log$ return is a non-linear function of log prices and dividends. With approximation around a first-order Taylor expansion of the mean price-dividend ratio:

$r_{t} \approx k+\rho P_{t}+(1-\rho) d_{t}-p_{t-1}$ Where $\mathrm{k}$ and $\rho$ are linearization parameters.

\section{Data and Methodology}

\subsection{Data}

The data employed in this study consists of annual data for stock price, dividend yield and final consumption expenditure for twelve Sub-Saharan African countries based on data availability. The countries included in the study are: Botswana, Cote d'Ivoire, Ghana Kenya, Malawi, Mauritius, Namibia, Nigeria, South Africa, Swaziland, Uganda and Zimbabwe. Due to the fact that many stock markets in the region are at infancy stage, the data used only covers the period 1988-2012. In all, three hundred observations were made and used for each variable in our panel data analysis. All the data were sourced from World Development Indicators (WDI) .

Table 1 presents the descriptive statistical properties of the data employed in the study: Stock price, Dividend yield and consumption. The results obtained are not different from typical macroeconomic data properties whereby the mean of the series is generally smaller than the standard deviation. Also, Jarque-Bera Statistics show that the series are normally distributed as the probability is significant at $1 \%$ significant level for the three variables.

Table 1. Descriptive statistics of the data

\begin{tabular}{cccc}
\hline & Stock Price & Consumption Growth & Dividend Yield \\
\hline Mean & 7.413687 & 85.96824 & 8.006083 \\
Median & 0.639397 & 86.58391 & 4.098086 \\
Maximum & 148.7733 & 121.4600 & 64.26132 \\
Minimum & 0.000000 & 49.82319 & 0.000000 \\
Std. Dev. & 22.54845 & 11.46949 & 11.76472 \\
Skewness & 4.279659 & -0.447335 & 2.929426 \\
Kurtosis & 22.17086 & 3.843005 & 11.52389 \\
Jarque-Bera & 4205.812 & 16.62200 & 1016.338 \\
Probability & 0.000000 & 0.000246 & 0.000000 \\
\hline
\end{tabular}




\begin{tabular}{cccc}
\hline Sum & 1697.734 & 22695.62 & 1825.387 \\
Sum Sq. Dev. & 115922.6 & 34597.43 & 31418.77 \\
Observations & 229 & 264 & 228 \\
\hline
\end{tabular}

Notes: The panel comprises of all the data from twelve selected countries in the Sub Saharan African region and they were introduced at their natural log difference based on data obtained from World Bank Development Indicators.

Also, in an effort to determine the strength of the relationship among our variables, Pearson correlation test was also conducted and the results are reported in Table 2. From the results, it is indicated that there exists a strong relationship between dividend yield and stock market price while consumption growth has a weak negative relationship with dividend yield and stock market price.

Table 2. Correlation relationship of dividend yield, consumption and stock price

\begin{tabular}{cccc}
\hline & Dividend Yield & Consumption & Stock Price \\
\hline DY & 1.000000 & & \\
CM & -0.059759 & 1.000000 & \\
SP & 0.937579 & -0.024514 & 1.000000 \\
\hline
\end{tabular}

\subsubsection{Econometric Properties}

Prior our estimation, econometric properties of the data were tested using different panel unit root tests as proposed by Pesaran and Shin (1997), Levin Lin and Chu (2002) and other forms of stationary tests. The results from all the tests support stationarity hypothesis for all the variables .This implies that all the variables: consumption growth, stock price and dividend yield are I(0) i.e. stationary at level. From these results, it is safe to conclude that dividend yield is an error-correction term in the context of price and dividend co-integration and thus deviation of prices from fundamentals represents transitory changes. This is in line with Cambell and shiller, (1987) and (1988a, b). The results of the tests are presented in Table 3.

Table 3. Panel unit tests

\begin{tabular}{lccc}
\hline & Consumption growth & Stock Price & Dividend yield \\
\hline LLU & $-2.94(0.00)$ & $-8.44(0.00)$ & $-4.30(0.00)$ \\
IPS & $2.31(0.010)$ & $-6.13(0.00)$ & $-4.01(0.00)$ \\
Fisher-ADF & $41.61(0.1)$ & $69.10(0.00)$ & $72.18(0.00)$ \\
Fisher-PP & $40.75(0.01)$ & $69.43(0.00)$ & $84.37(0.00)$ \\
Hadri & $7.24(0.00)$ & $10.48(0.00)$ & $10.67(0.00)$ \\
\hline
\end{tabular}

Source: Author's computation based on WDI data.

Despite satisfactory results from our unit root tests, we also attempted co-integration analysis for our model to satisfy our statistical curiosity on one hand and to prevent misspecification problem on the other hand. To this end, Pedroni and Johansen Fisher Panel Cointegration test were employed. The results for Pedroni is presented in Table 4 and it shows that the null hypothesis of no co-integration is rejected for our model at $1 \%$ significant level thus suggesting long term relationship in the variables. Similarly, Johansen Fisher Panel Cointegration results presented in Table 5 also rejects the hypothesis of no co-integration for our model. 
Table 4. Pedroni co-integration result

\begin{tabular}{cccllll}
\hline & \multicolumn{3}{c}{ AR coefs.(within-dimention) } & & \multicolumn{3}{c}{ Individual AR. coef.(between dimention } \\
\hline P.v-stat & P.rho-stat & P.pp-stat & P.ADF-stat. & G.rho-Stat & G.pp-stat & G.ADF.stat \\
-0.334897 & -4.658523 & -11.79968 & -4.589637 & -2.062915 & -11.01809 & -4.172123 \\
$(0.6311)$ & $(0.0000)$ & $(0.0000)$ & $(0.0000)$ & $(0.0196)$ & $(0.0000)$ & $(0.0000)$ \\
\hline
\end{tabular}

Table 5. Johansen fisher panel cointegration test: (trace and maximum eigenvalue)

\begin{tabular}{lcccc}
\hline Hypothesized & Fisher Stat. $^{*}$ & Prob. & Fisher Stat.* & Prob. \\
\hline No. of CE(s) & (from trace test) $^{*}$ & & (from max-eigen test) & \\
None & 68.32 & 0.0000 & 50.19 & 0.0001 \\
At most 1 & 34.75 & 0.0102 & 27.04 & 0.0783 \\
At most 2 & 38.31 & 0.0035 & 38.31 & 0.0035 \\
\hline
\end{tabular}

Notes* Probabilities are computed using asymptotic Chi-square distribution.

\subsubsection{Model Estimation}

To estimate our model, dynamic generalized moment method (GMM) was employed and this is largely due to short time nature of the data used and the ability of the technique to give efficient result despite temporal autocorrelation in the residual and persistency in the dependent variables Franz (2009).

$$
C g_{i t}=S p_{i t}+D y_{i t}+e_{i t}
$$

In equation above $\mathrm{Cg}$ represents consumption growth, $S p$ represents the stock price and inflation, Dy represents dividend yield. Also $i$ stands for cross section which comprises of selected sub-Sahara African countries and $\mathrm{t}$ represents time

The results of our model estimation as presented in table 6 shows that the lag value of consumption has a significant positive effect on current consumption which is statistically significant at $1 \%$ and this helps to cater for likely autocorrelation threat in the model. Also, dividend yield demonstrates a positive effect on contemporaneous consumption and this indicates that an increase in dividend yield will spur increasing consumption. However, the result is not statistically significant as the p-value is less than 0.05 but it is line with Cambell (2003) who argues that positive relationship between dividend yield and consumption can be linked to changes in discount rate. In a similar manner, contemporaneous stock price exhibits positive effect on consumption and this supports a standard wealth effect view where an increase in total wealth effect results in increased consumption. The result is significant at $1 \%$ significant level and it establishes the existent of wealth effect

Table 6. GMM estimate of consumption, dividend yield and stock price

\begin{tabular}{lccc}
\hline Variable & Coefficient & t-statistic & Prob. \\
\hline Consumption(-1) & 0.176262 & 28.17243 & 0.0000 \\
D(Dividend Yield) & 0.024994 & 0.855346 & 0.3939 \\
D(Stock Price) & 0.205783 & 4.129148 & 0.0001 \\
J-Statistic & 6.6 & & \\
Instrument Rank & 10 & & \\
No of Observations & 300 & & \\
Cross Section Included & 12 & & \\
\hline
\end{tabular}

\section{Conclusion and Implication}

Based on our findings, the study concludes that there is a strong existence of wealth effect in consumption in selected sub-Saharan African countries. Similarly, consumption in the region also responds positive to short-term 
deviation of price (bubbles) though in weak manner. These findings imply that, since consumption has been identified as a key ingredient of economic growth thus it is safe to conclude an improved performance of firms which is capable of increasing their share valuation matters for economic growth in the region. This provides another channel for government in the sub-region to stimulate economic growth by providing enabling environment for firms to perform optimally rather than resorting to cosmetic approach of causing bubbles in the market. Also, the study establishes that dividend yield performs the role of error-correction mechanism since the variable is order of degree one and this is a typical behaviour of the variable in many advanced economies. This suggests that dividend yield can as well serve as an important signal to players in the stock exchange market in the sub-region.

\section{References}

Bayoumi, T. (1993). Financial deregulation and household saving. The Economic Journal, 103, 1432-1443. http://dx.doi.org/10.2307/2234475

Beck, T. (2006). Creating and efficient financial system: Challenges in global economy. World Bank Research Working Paper 3856, Washington: The World Bank. http://dx.doi.org/10.1596/1813-9450-3856

Bhatia, K. B. (1972). Capital gains and aggregate consumption function. The American Economic Review, 62, 866-879.

Brayton, F., \& Tinsley, P. (1996). A guide to FRB/US-A macroeconomic model of the US federal reserve board, macroeconomic and quantitative studies. Division of Research and Statistics.

Cagan, P. (1990). The 1987 stock market crash and the wealth effect. In P. A. Klein (Ed.), Analyzing modern business cycles, essays honoring.

Caporale, G. M., \& Williams, G. (1997). Revisiting forward looking consumption and financial liberalisation on in the United Kingdom. London Business School DP No.xx-97.

Case, K. E., Quigley, J. M., \& Shiller, R. (2001). Comparing wealth effects: The stock market versus the housing market. NBER Working Paper: 8606.

Christopher, D. C. (1992). How does future income affect current consumption? Working Paper Series/ Economic Activity Section 126, Board of Governors of the Federal Reserve System.

David, G. M. (2013). Consumption and stock prices: Evidence from a from a small international panel. Journal of Macroeconomics, 36, 78-88.

Deaton. \& Angus. (1991). Saving and liquidity constraints. Econometrica, 59(5), 1221-48. http://dx.doi.org/10.2307/2938366

Enisan, A. A., \& Olufisayo, A. O. (2009). Stock market development and economic growth: Evidence from seven Sub-Sahara African countries. Journal of Economics and Business, 61(2). http://dx.doi.org/10.1016.j.j econbus.2008.05.001

Friedman, M. (1957). A theory of the consumption function. Princeton: NBER.

Gelbard, E. A., \& Leite, S. P. (1999). Measuring financial development in Sub-Saharan Africa. IMF Working Paper 99/105, Washington: International Monetary Fund.

Hall, R. (1978). Stochastic implications of the life-cycle permanent income hypothesis: Theory and evidence. Journal of Political Economy, 86, 971-987. http://dx.doi.org/10.1086/260724

John, M. K. (1936). The general theory of employment. Interest and Money, 12.

Laitner, J., \& Juster, F. T. (1996). New evidence on altruism: A study of TIAA-CREF retirees. American Economic Review, 86(4), 893-908.

Lettau, M., \& Sydney, L. (2004b). Understanding trend and cycle in asset values: Bulls, bears, and the wealth effect on consumption. American Economic Review, 94(1), 279-299. http://dx.doi.org/10.1257/000282804322970805

Levin, A., Lin, C. F., \& Chu, C. S. J. (2002). Unit root tests in panel data: Asymptotic and finite sample properties. Journal of Econometrics, 108,1-22. http://dx.doi.org/10.1016/S0304-4076(01)00098-7

Levine, \& Ross. (1997). Finance and growth: Views and agenda. Journal of Economic Literature, 35(2), 688726.

Ludwig, A., \& Slok, T. (2002). The impact of changes in stock prices and house prices on consumption in OECD 
countries. International Monetary Fund Working Paper:02/1.

Mankiw, H. G., \& Zeldes, S. P. (1991). The consumption of stockholders and non-stockholders. Journal of Financial Economics, 29, 97-112. http://dx.doi.org/10.1016/0304-405X(91)90015-C

McMillan, G. D. (2013). Consumption and stock prices: Evidence from a small international panel. Journal of Macroeconomics, 36, 76-88. http://dx.doi.org/10.1016/j.jmacro.2013.01.007

Modigaliani, F. A. (1963). The life-cycle hypothesis of saving implication and tests. America Economic Review, $103,55-84$.

Modigliani, F. (1971). Monetary policy and consumption. consumer spending and monetary policy: The linkages. Federal Reserve Bank of Boston, Conference Series No.5.

Modigliani, F., \& Brumberg, R. H. (1954). Utility analysis and the consumption function: An interpretation of cross-section data. In K. K. Kurihara (Ed.), Post-keynesian economics (pp. 388-436). New Brunswick: Rutgers University press.

Modigliani, F., \& Brumberg, R. H. (1980). Utility analysis and aggregate consumption functions: An attempt at integration. In A. Abel (Ed.), The collected papers of franco Modigliani, the life cycle hypothesis of saving (Vol. 2, pp. 128-197). Cambridge, MA: The MIT Press.

Parker, \& Jonathan, A. (1999c). The consumption function re-estimated. Princeton University: Mimeo.

Pesaran, M. H., \& Shin, Y. (1997). Long-run structural modeling. Unpublished manuscript, University of Cambridge. Retrieved from http:// www.econ.cam.ac.uk/faculty/pesaran/

Regional Economic Outlook. (2006). Sub-Saharan Africa. Washington: International Monetary Fund.

Starr-McCluer, M. (1998). Stock market wealth and consumer spending, board of governors of the federal reserve system. Finance and Economics Discussion Paper Series 98/20.

Starr-McCluer, M. (2000). Stock market wealth and consumption. Federal Reserve Board: Mimeo.

Whilhelm, O. M. (1996). Bequest behavior and the effect of heirs' earning: Testing the Altruistic Model of Bequests. American Economic Review, 86(4), 874-892.

Yartey, A. C., \& Adjasi, C. K. (2007). Stock market development in Sub-Saharan Africa: Critical issues and challenges. IMF Working paper 07/209, Washington: International Monetary Fund.

\section{Copyrights}

Copyright for this article is retained by the author(s), with first publication rights granted to the journal.

This is an open-access article distributed under the terms and conditions of the Creative Commons Attribution license (http://creativecommons.org/licenses/by/3.0/). 